\title{
PROBLEM OF SELECTION OF SUITABLE GEOSYNTHETICS FOR THE STRENGTHENING OF SUBGRADE IN ROAD CONSTRUCTION, SELECTION OF ASSESSMENT CRITERIA
}

\author{
Elżbieta Szafranko ${ }^{\bowtie}$ \\ Faculty of Geoengineering, University of Warmia and Mazury in Olsztyn, Olsztyn, Poland
}

\begin{abstract}
The introduction of geosynthetics into road construction significantly facilitated fulfilment of the set of requirements for modern road building technologies. The fact that geosynthetic materials can be implemented at all stages, from earthwork through land drainage to the construction of layers of roads, new, repaired or strengthened ones, means that geosynthetics now occupy an important place in contemporary road building technologies. Industry supplies numerous materials classified as geosynthetics. In line with the standard PN-EN ISO 10318:2007, we distinguish four principal groups of these products: geotextiles, geotextile derivatives, geosynthetic barriers and geocomposites. The industrially produced materials have various properties, which means they have different applicability. This paper analyses basic characteristics, which decide how geosynthetics can be used. Because of a large number of features and factors that could apply to an evaluation of specific solutions, it is necessary to include a large group of criteria. Their analysis might be cumbersome, and therefore an approach is suggested which will greatly facilitate making a complex assessment and selection of a solution which will best meet the customer's expectations. The assessment of the extent to which specific criteria are met by the geosynthetic materials selected for an analysis allows us to gain better understanding of their suitability and proper choice, supported by multifactorial analytical methods. The theme of the article is a preliminary step which is to prepare and organize the relevant characteristics of geosynthetics and define the major groups of criteria and sub-criteria.
\end{abstract}

Key words: geosynthetics, classification, functions of geosynthetics, assessment criteria

\section{INTRODUCTION}

The past few years have witnessed a dynamic growth of technologies of geosynthetic reinforced soil technologies (Brózda \& Selejdak, 2019). The underlying motivation was to search for new ways to found building constructions which would be less time-consuming while satisfying all technical requirements, as well as being economically viable and technically feasible. The geosynthetics produced today are fabricated from such plastics as poly(vinyl chloride), polypropylene, polyethylene, polyesters, polyamides, etc. (Bathurst, 2007; Sobolewski, 2010; Shukla, 2011; Szruba, 2014a, 2014b; Polski Komitet Normalizacyjny [PKN], 2015). The choice of a type and kind of a geosynthetic for a particular development plan should be based on the expected physical and technological properties of this material (Bugajski \& Grabowski, 1999; Keller, 2016). The classification of geosynthetics illustrates Figure 1.

The materials listed in the standard PN-EN ISO 10318:2007, composing the group of geotextiles, are: 


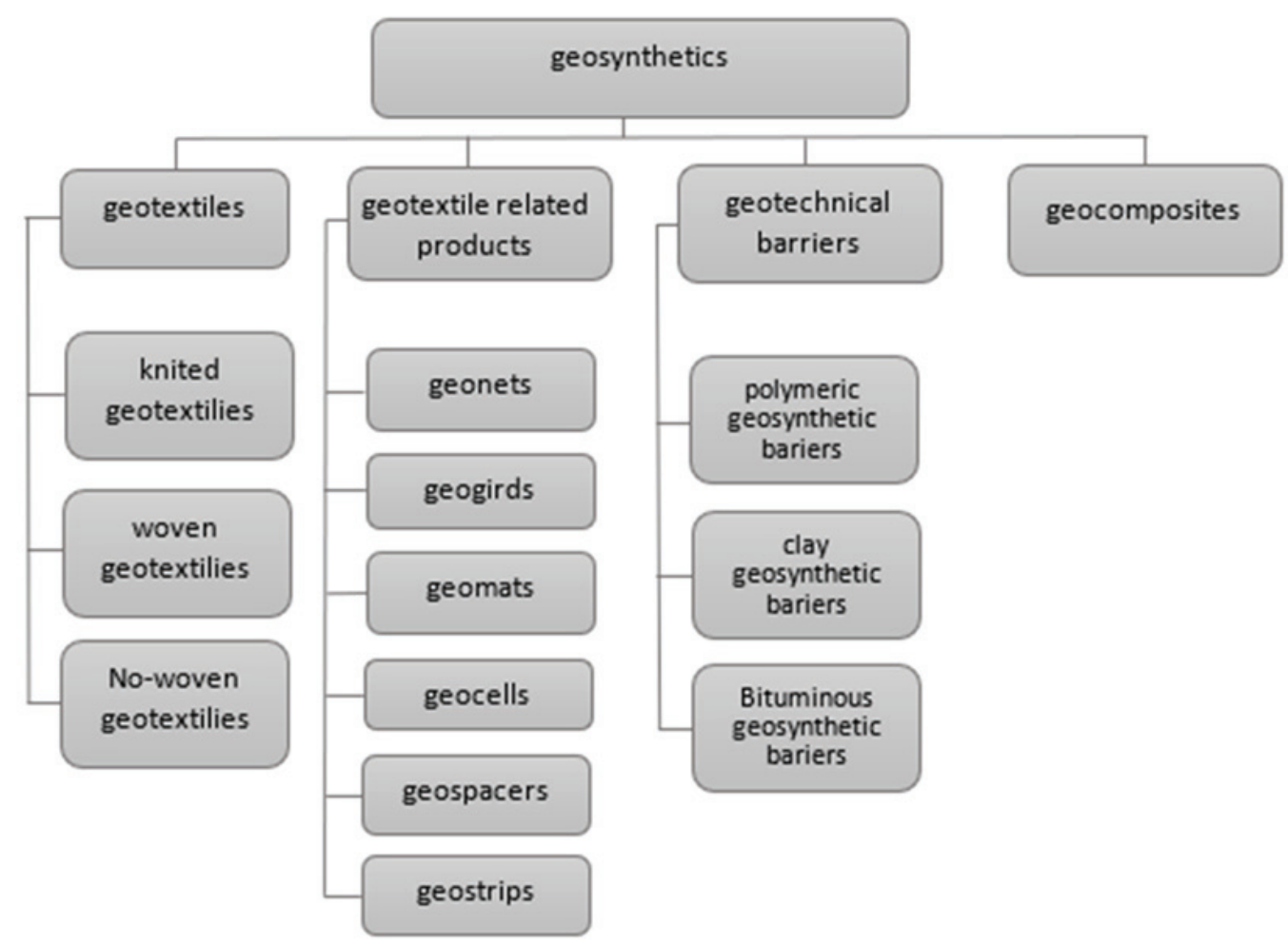

Fig. 1. Classification of geosynthetics according to the standard PN-EN ISO 10318:2007

- woven geotextiles (GTX-W) - made with the traditional weaving method from polypropylene and polyester fibers, yarns or tapes. These are made into an orderly, compact warp and weft structure by being interlaced perpendicularly to each other.

- non-woven geotextiles (GTX-N) - are planar, non-woven textile products, made with chemical and thermal adhesion methods. They come in two variants: for filtration and for separation and filtration.

- knitted geotextiles (GTX-K) - are produced by interloping one or more yarns. They are highly elastic. They can be made as planar materials or in the shape of pipes.

Geotextiles are the products composing the major group of permeable materials (Ajdukiewicz, 2004; Czarnecka, 2016; Keller, 2016).

The second most numerous group of products, described in the aforementioned standard, are geotextile-related products (GTP). The group comprises quite diverse products, such as:
- geonets (GNT) - they are polymeric products, presenting a regular layout of a flat, open, netlike configuration of longitudinal and perpendicular ribs, connected at intersections thermally or by extrusion, adhesion or interlacing, which typically creates apertures larger than the ribs. Geonets are used for reinforcement in the construction of earth retaining structures;

- geogrids (GGR) - consist of two-parallel sets of ribs, permanently connected and intersecting each other at any angle. They are usually applied in combination with geotextiles in drainage geocomposites;

- geocells (GCE) - are three-dimensional, permeable products with a honeycomb structure. Other names given to geocells are cellular confinement systems or cellular geosynthetics;

- geostrips (GST) - are planar products of the thickness of no more than $200 \mathrm{~mm}$, most often used in combination with other geosynthetics;

- geomats (GMA) - are made from polypropylene filaments arranged in a three-dimensional 
configuration of the thickness up to $20 \mathrm{~mm}$. Geomats are used for permanent or temporary protection of slopes against erosion until natural vegetation cover develops;

- geospacers (GSP) - polymeric products used to create air spaces in soil (Szafranko, 2014a; Szruba, 2014a; Cristelo, Vieira \& de Lurdes Lopes, 2016; Zornberg, 2017).

The third group of geosynthetics distinguished in the PL-EN ISO 10318:2007 standard are geosynthetic barriers (Gradkowski, 2007; Lawson, 2008; Huang, Han \& Oztoprak, 2009), that is non-permeable materials, known as geomembranes. Examples are:

- polymeric geosynthetic barriers (GBR-P) - completely impermeable products, including geomembranes, popular in Poland;

- clay geosynthetic barriers (GBR-C) - known mainly as bentonite mats, bent mats, etc., where the function of a barrier is performed by a clay material;

- bituminous geosynthetic barriers (GBR-B) where the role of a barrier is played by a bituminous material.

The last group encompasses geocomposites - they are products composed of two or more interconnected materials having properties which can satisfy the set of requirements in order to achieve the best possible effect in the range of functions performed by a given composite material. Depending on the dominant function of a geocomposites, it can be a combination of geogrids, geonets, geomats, geotextiles or geomembranes with non-woven geotextiles (Koerner, Hsuan \& Koerner, 2007; Szczygielski \& Stopa, 2014).

\section{FUNCTIONS AND APPLICATIONS OF GEOSYNTHETICS}

As suggested in the above standard, geosynthetics can play the folwing roles (Horodecki \& Duszyńska, 2017; Gołoś, 2019; Miszkowska, 2019):

- dewatering - when a geosynthetic is to drain and discharge ground water within the layer where a geotextile or geotextile-related material is placed;

- filtration - when a geosynthetic enables the flow of fluids through a geotextile layer while preventing the passage of soil particles;
- protection of protective coating for a protected object - a layer which receives external impacts, e.g. mechanical stresses, or the effects of wind, rain, waves, rock debris, etc.;

- reinforcement - using a geosynthetic to improve the mechanical properties of soil or other construction materials;

- separation - separating layers in order to prevent the mixing of different soils or other materials;

- superficial protection - protecting the surface against erosion, including soil erosion, landslide, etc.;

- barriers - using a geosynthetic in order to prevent the passage of fluids (water).

Examples of applications of geosynthetics are (Bhatia, Smith \& Christopher, 1996):

- separation of weak subgrade under a slope or embankment in order to improve stability and accelerate consolidation;

- construction of makeshift roads, as well as roads in woodlands or on farmlands, construction of car parks and parking spaces in sites with difficult soil and water conditions;

- making separating and dividing layers in fine-grained soils;

- making subgrade layers which retain soil under geonets or geogrids in the construction of reinforced slopes and embankments;

- protection of drainage systems in order to prevent their silting with fine-grained soils;

- protection of geomembrane seals against mechanical damage.

When roads are built on embankments, geosynthetics enables to decrease the thickness of an embankment while maintaining the bearing capacity. Geosynthetics are most often used in a subgrade composed of aggregate. The exact location of a geosynthetic in the subgrade depends on the bearing capacity of the soil and the quality of aggregate. When good quality aggregate is used and the bearing capacity of the subgrade is large, one layer of a geosynthetic is sufficient. If both the aggregate and subgrade are poor, it is necessary to use two layers of a geosynthetic. Poor aggregate on a strong subgrade will necessitate the application of a geosynthetic reinforcement within the layer. Geotextiles, geocomposites or nets placed on geotextiles can be introduced at the contact zone of the foundation and 
subgrade (Palmeira, Tatsuoka, Bathurst, Stevenson \& Zornberg, 2008). The internal reinforcement in the layer of aggregate is always made of geonet. It is also possible to reinforce the foundation by using geocells on geotextiles. Geonets and geotextiles can also be applied as reinforcement in the road pavement (Brózda, Selejdak \& Koteš, 2017).

\section{THE PROBLEM OF SELECTION OF THE RIGHT GEOSYNTHETIC - METHODOLOGY}

Materials employed to strengthen the subgrade using a geosynthetic should respond to the requirements specified in the design. The durability of geosynthetics under average conditions is very good, but it depends on the resistance to atmospheric (climatic) factors as well as to chemical and biological effects (Frost \& Lee, 2001; Koerner, 2012). In road construction, durability tests are only required under specific conditions, for example when it is not planned to cover the product directly with soil or when particular environmental risks are present. In general, a geosynthetic should be protected from UV radiation, for example by using certain additives, such as soot, which makes geosynthetics resistant even to long-term exposure (Gradkowski \& Żurawski, 2003; Gradkowski, 2008). However, it is recommended to incorporate geosynthetics into a construction promptly and to cover them with ground.

When selecting the type of a geosynthetic for strengthening a construction, in each case it is recom- mended to pay attention to several properties of such products, including:

- physical properties: mass per unit area, thickness, specific density, porosity;

- mechanical properties: tensile strength (longitudinal and transverse), elongation at failure, creep at tension and compression, static and dynamic puncture strength;

- hydraulic properties: longitudinal and transverse water permeability, size of pores;

- rheological properties: resistance to atmospheric conditions, gradual change in parameters with time;

- implementation (technological and economic) properties: time needed to implement, use of specialist equipment, prices for hiring equipment, qualified staff needed to be employed, availability of materials, prices of materials;

- environmental considerations: the impact on the natural environment, reduction in emissions of harmful substances and exhaust gases, the impact on the soil and water balance on a local scale and globally.

The correct choice of geosynthetics can be guided by the information comprised in the table, which is based on general guidelines and functions intended for groups of products to be performed, although specific characteristics, typical of each product, must be in agreement with the specific requirements set by a building designer in each case (Szafranko, 2014a).

Table. Functions of the geosynthetics and their types

\begin{tabular}{|c|c|c|c|c|c|c|}
\hline \multirow{2}{*}{ Type of geosynthetic } & \multicolumn{6}{|c|}{ Function } \\
\hline & separation & filtration & drainage & reinforcement & protection & barrier \\
\hline Geotextiles & $\mathrm{x}$ & $\mathrm{x}$ & $\mathrm{x}$ & $\mathrm{x}$ & $\mathrm{x}$ & \\
\hline Geogrids & & & $\mathrm{x}$ & $\mathrm{x}$ & & \\
\hline Geonets & & & $\mathrm{x}$ & $\mathrm{x}$ & & \\
\hline Geomembranes & $\mathrm{x}$ & & $\mathrm{x}$ & & & $\mathrm{x}$ \\
\hline Gemmates & $\mathrm{x}$ & & & $\mathrm{x}$ & $\mathrm{x}$ & \\
\hline Geocomposites & $\mathrm{x}$ & $\mathrm{x}$ & $\mathrm{x}$ & $\mathrm{x}$ & $\mathrm{x}$ & $\mathrm{x}$ \\
\hline
\end{tabular}

Source: Own elaboration based on Brózda and Selejdak (2019). 


\section{RESULTS AND DISCUSSION}

In order to make the right choice of a geosynthetic, a well-ordered system approach is necessary. There are many ways in which the selection procedure can be ordered. In practice, it amounts to the separation of decision-making process stages (Fig. 2). Although the chosen method supporting making a decision when a large group of criteria must be considered is usually one of the multifactorial analysis methods, one of the most significant stages is the one when a list of criteria to be assessed is being prepared, with each parameter assigned its weight of importance in the light of a given design plan.

The first step in the diagram (Fig. 2) is to make a list of criteria for the subsequent assessment, which in our case means an evaluation of various material (geosynthetics) solutions and an appraisal of their value (Szafranko, 2013). The objective is to achieve a detailed assessment of the factors which in various ways influence the final decision, and to identify a few feasible variants of the planned development. The list of assessment criteria and their importance depend on a goal to be attained and what investment actions have been planned.

One set of criteria will apply to a task of strengthening the soil under an embankment, another one when the foundation is to be reinforced, and yet another one when the planned project is to make the wearing course of a road pavement. The same criterion could be considered as very important in one case, but shown to be unimportant in another one (Szafranko, 2017). The evaluation of the project variants and a selection of the best solution may seem to be a relatively straightforward task, yet when making a list of criteria and subsequently evaluating them, errors may occur which will bear an impact on the ultimate outcome of the analysis. Hence, this stage requires particular attention and care.

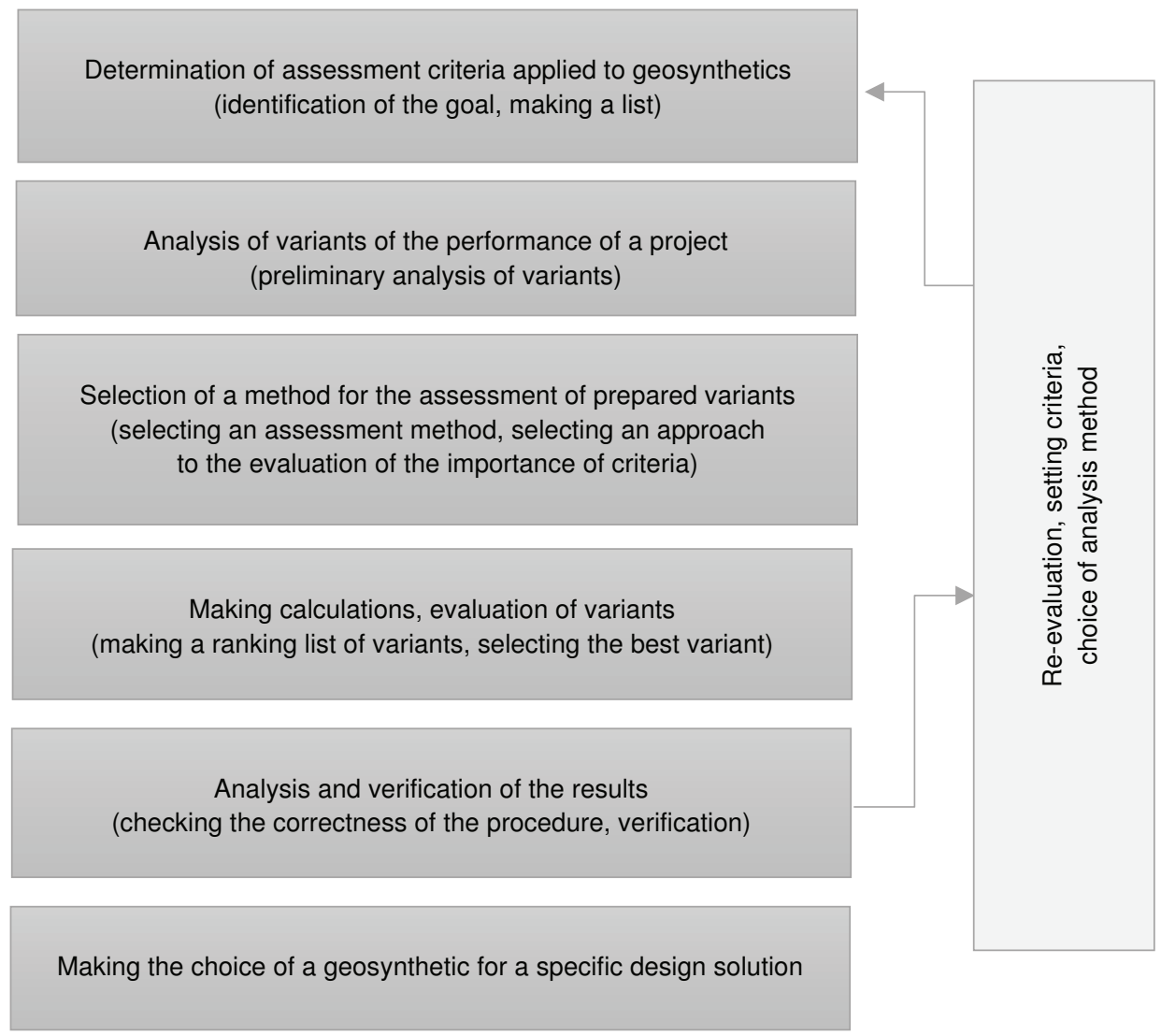

Fig. 2. Diagram of the decision-making procedure (own elaboration) 
The geosynthetics described and classified according to the standard PN-EN ISO 10318:2007 demonstrate certain features and are characterized by specific technical, mechanical and other properties. Due to their large diversity, it is recommended to divide them into main criteria and subcriteria. A suggestion which criteria could be distinguished as useful ones in the consecutive stages of an assessment is given in Figure 3.
Criteria arranged according to Figure 3 can be submitted to further analysis. In order to determine their importance, it is necessary to obtain opinions from experts. To carry out this stage, experts are requested to complete specially prepared research questionnaires.

Questionnaires must be adjusted to the planned analytical method and the assessments given by interviewed experts should be based on a suitably chosen

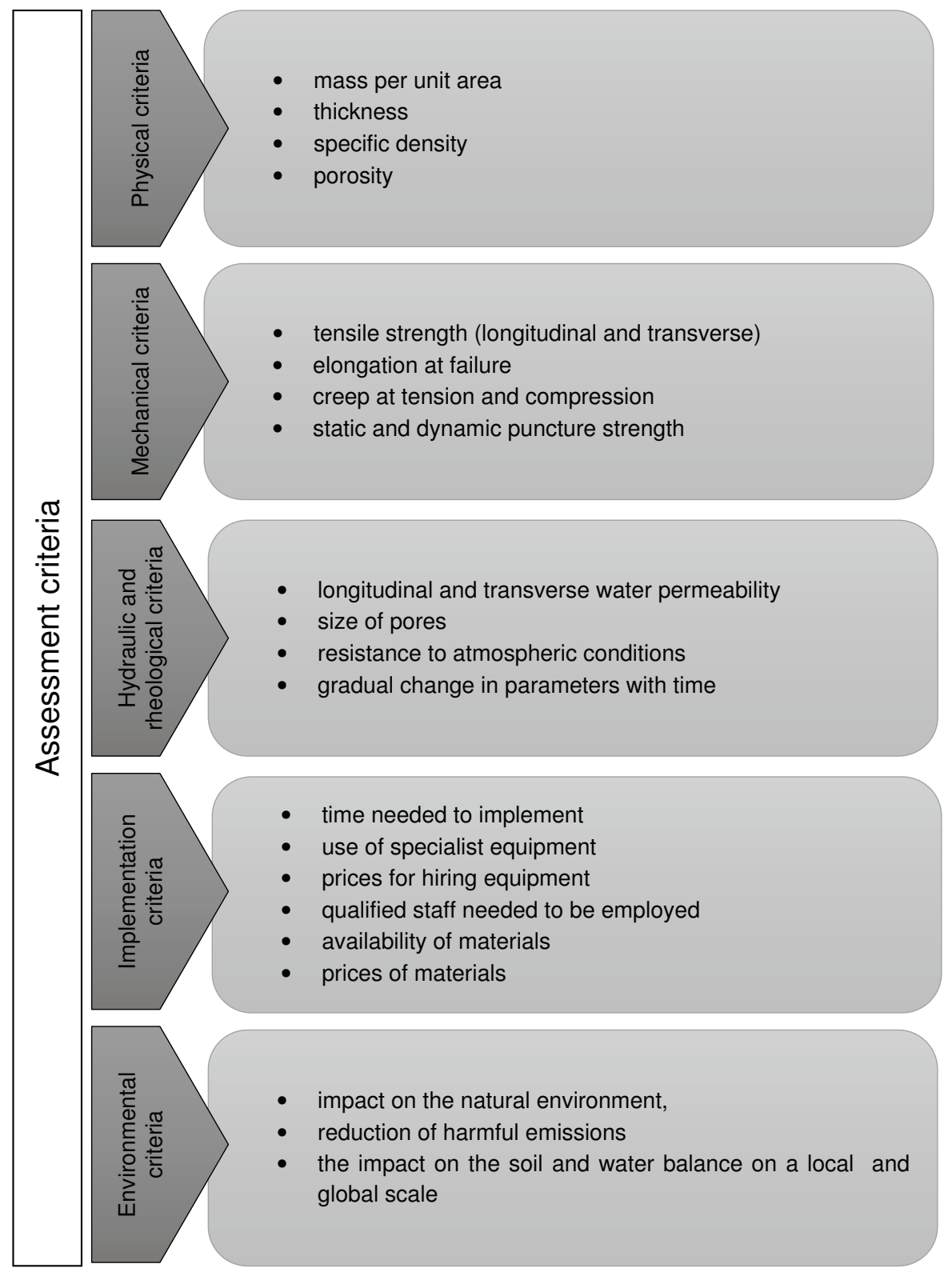

Fig. 3. Proposed criteria for assessing geosynthetics (own elaboration) 
scale while the provided responses ought to be given in line with the proposed method. Various scales are applicable (different ranges and specificity), in addition to which there could be different methods of giving answers (statistical, descriptive, linguistic) or methods for giving score evaluations of non-measurable events.

The assessments of criteria achieved as explained beforecan serve as a reliable database to make an analysis supported by the previously chosen multifactorial analytical method. Such methods are very useful when an evaluation must take into account large groups of factors that decide about the final selection of the optimal solution.

An assessment can be accomplished with point or weight-point scalarization methods, with pairwise comparison of criteria or by binary dominance relations.

\section{SUMMARY AND CONCLUSIONS}

A wide range of geosynthetics made by both domestic and international industries means that these materials can be applied broadly in civil engineering and road construction. The large diversity of such products, however, necessitates selection of such solutions which would best satisfy the set of requirements, for example, in the road building practice. Different geosynthetics having different mechanical, technical or economic characteristics are selected for different building projects. In order to improve the process of selecting geosynthetics, the author proposes a methodology for supporting the decision-making process. The suggested procedure can be summarized on Figure 4.

The procedure described above makes it possible enables to choose the correct geosynthetic for a given purpose, and to take into account all significant criteria while considering the requirements specific for a given design plan.

\section{REFERENCES}

Ajdukiewicz, J. (2004). Projektowanie z geosyntetykami - możliwe zagrożenia dla projektantów - cz. I. Magazyn Autostrady, 5, 84-90.

Bathurst, R. J. (2007). Geosynthetics Classification. IGS Leaflets on Geosynthetics Applications. Austin, TX: IGS Education Committee.

Bhatia, S. K., Smith, J. L. \& Christopher, B. R. (1996). Geotextile characterization and pore-size distribution: Part III. Comparison of methods and application to design. Geosynthetics International, 3 (3), 301-328.

Brózda, K. \& Selejdak, J. (2019). The Functions of the Geosynthetics in Roadway Applications. Acta Sci. Pol. Architectura, 18 (2), 27-31. https://doi.org/10.22630/ ASPA.2019.18.2.19

Brózda, K., Selejdak, J. \& Koteš, P. (2017). Analysis of Properties of the FRP Rebar to Concrete Structures. Applied Engineering Letters, 2 (1), 6-10. https://doi. org/10.1016/j.proeng.2017.06.011

Bugajski, M. \& Grabowski, W. (1999). Geosyntetyki w budownictwie drogowym. Poznań: Wydawnictwo Politechniki Poznańskiej.

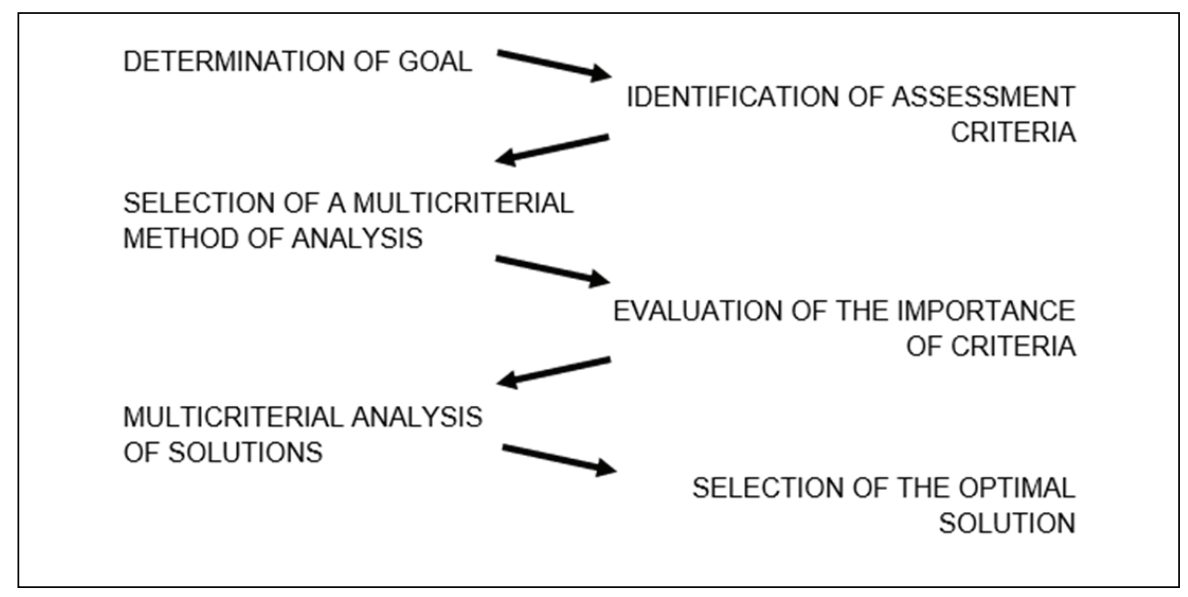

Fig. 4. Proposed scheme solution of the problem (own elaboration) 
Cristelo, N., Vieira, C. S. \& Lurdes Lopes, M. de (2016). Geotechnical and geoenvironmental assessment of recycled construction and demolition waste for road embankments. Procedia Engineering, 143, 51-58. https://doi.org/10.1016/j.proeng.2016.06.007

Czarnecka, K. (2016). Geosyntetyki - przegląd materiałów wzmacniających podłoże o słabych parametrach geotechnicznych [Geosynthetics - a review of reinforcing materials substrate with poor geotechnical parameters]. Archiwum Instytutu Inżynierii, 22, 93-104. https://doi. org/10.21008/j.1897-4007.2016.22.07

Frost, J. D. \& Lee, S. W. (2001). Microscale study of geomembrane-geotextile interactions. Geosynthetics International, 8 (6), 577-597. https://doi.org/10.1680/ gein.8.0207

Gołoś, M. (2019). Funkcja stabilizacyjna geosyntetyków. Geoinżynieria: Drogi, Mosty, Tunele, 4, 64-68.

Gradkowski, K. (2007). Geosyntetyki w budowie dróg zasady stosowania geosyntetyków o n-tym kierunku wzmocnienia. Inżynier Budownictwa, 7-8, 36-41.

Gradkowski, K. (2008). Efekt wzmocnień geotekstyliami gruntowego podłoża nawierzchni dróg - badania doświadczalne. Drogi i Mosty, 4, 5-22.

Gradkowski, K. \& Żurawski, S. (2003). Budowle i roboty ziemne. Warszawa: Oficyna Wydawnicza Politechniki Warszawskiej.

Horodecki, G., \& Duszyńska, A. (2017). Dobór geotekstyliów i wyrobów pokrewnych pełniących funkcję zbrojenia w budownictwie komunikacyjnym - wybrane problemy inżynierskie [Selection of geotextiles and related reinforcement products in transportation engineering - selected engineering issues]. Magazyn Autostrady, $11-12,42-46$.

Huang, J., Han, J. \& Oztoprak, S. (2009). Coupled mechanical and hydraulic modeling of geosynthetic-reinforced column-supported embankments. Journal of Geotechnical and Geoenvironmental Engineering, 135 (8), 1011-1021.

Keller, G. R. (2016). Application of geosynthetics on lowvolume roads. Transportation Geotechnics, 8, 119-131. https://doi.org/10.1016/j.trgeo.2016.04.002

Koerner, G. R., Hsuan, Y. G. \& Koerner, R. M. (2007). The durability of geosynthetics. Chapter 3. In R. W. Sarsby (Ed.), Geosynthetics in Civil Engineering (pp. 36-65). Sawston, Cambs.: Woodhead Publishing.

Koerner, R. M. (2012). Designing with geosynthetics. Vol. 1. 6th ed. Bloomighton, IN: Xlibris.

Lawson, C. R. (2008). Geotextile containment for hydraulic and environmental engineering. Geosynthetics In- ternational, 15 (6), 384-427. https://doi.org/10.1680/ gein.2008.15.6.384

Miszkowska, A. (2019). Funkcja filtracyjna geosyntetyków. Geoinzynieria: Drogi, Mosty, Tunele, 2, 44-46.

Palmeira, E. M., Tatsuoka, F., Bathurst, R. J., Stevenson, P. E. \& Zornberg, J. G. (2008). Advances in Geosynthetics Materials and Applications for Soil Reinforcement and Environmental Protection Works. Electronic Journal of Geotechnical Engineering, 13, 1-38.

Polski Komitet Normalizacyjny [PKN] (2015). Geosyntetyki. Część 1: Terminy $i$ defnicje (PN-EN ISO 103181:2015). Warszawa: Polski Komitet Normalizacyjny.

Shukla, S. K. (2011). Handbook of Geosynthetic Engineering: Geosynthetics and Their Applications. London: ICE Publishing.

Sobolewski, J. (2010). Wymiarowanie zbrojeń geosyntetycznych w konstrukcjach $\mathrm{z}$ gruntu zbrojonego zgodnie z przepisami Eurokodu 7 [Design of geosynthetic reinforcements for earth structures in line with regulations of Eurocode 7]. Drogi i Mosty, 9 (2), 73-86.

Szafranko, E. (2013). Ocena ekspertów w analizach prowadzonych metodą AHP przy wyborze wariantów inwestycji. Inżynieria Morska i Geotechnika, 5, 400-404.

Szafranko, E. (2014a). Możliwości zastosowania geosyntetyków do wzmacniania skarp w budownictwie drogowym. Magazyn Autostrady, 3, 21-25.

Szafranko, E. (2014b). Metody analizy wariantów inwestycji drogowych. Drogownictwo, 1, 18-25.

Szafranko, E. (2017). Decision problems in management of construction projects. IOP Conference Series: Materials Science and Engineering, 251 (1), 012048. https://doi. org/10.1088/1757-899X/245/7/072026

Szczygielski, M. \& Stopa, Ł. (2014). Usage of new soil improvement techniques in road embankment constructions. Technical Transactions Civil Engineering, 2-B (6), 109-116.

Szruba, M. (2014a). Geosyntetyki. Cz. 1. Charakterystyka i funkcje według PN-EN ISO 10318:2007 [Geosynthetics Materials. Part 1. Characteristics and functions according to PN-EN ISO 10318:2007]. Nowoczesne Budownictwo Inżynierne, 4, 48-51.

Szruba, M. (2014b). Geosyntetyki. Cz. 2. Zastosowanie - podział według PN-EN ISO 10318:2007 [Geosynthetics. Part 2. The application - classification according PN-EN ISO 10318:2007]. Nowoczesne Budownictwo Inżynierne, 5, 86-88.

Zornberg, J. G. (2017). Functions and Applications of Geosynthetics in Roadways. Procedia Engineering, 189, 298-306. https://doi.org/10.1016/j.proeng.2017.05.048 


\section{PROBLEM WYBORU GEOSYNTETYKÓW DO WZMOCNIENIA PODŁOŻA W BUDOWNICTWIE DROGOWYM, DOBÓR KRYTERIÓW OCENY}

\section{STRESZCZENIE}

Wprowadzenie do budownictwa drogowego geosyntetyków w znacznym stopniu ułatwiło spełnienie wymogów stawianych nowoczesnym technologiom drogowym. Możliwość zastosowania materiałów geosyntetycznych począwszy od robót ziemnych przez odwodnienie aż do konstrukcji warstw nawierzchni (zarówno nowych, jak i remontowanych lub wzmacnianych) sprawia, że geosyntetyki zajmują ważne miejsce pośród nowoczesnych technologii drogowych. Przemysł dostarcza bardzo dużo materiałów kwalifikowanych jako geosyntetyki. Zgodnie z normą PN-EN ISO 10318:2007 wyróżniamy cztery zasadnicze grupy tych produktów: geotekstylia, geotekstylne wyroby pokrewne, bariery geosyntetyczne i geokompozyty. Materiały dostarczane przez przemysł mają różne właściwości, a co za tym idzie wielorakie zastosowania. W artykule przeanalizowano podstawowe cechy decydujące o możliwości wykorzystania geosyntetyków w różnych rozwiązaniach inżynierskich. Ze względu na dużą liczbę cech i czynników do oceny wybranych rozwiązań konieczne jest uwzględnienie znacznej grupy kryteriów. Ich analiza może przysparzać wiele problemów, dlatego też w artykule zaproponowano podejście pozwalające na kompleksową ocenę i wybór rozwiązania w najwyższym stopniu spełniającego oczekiwania klienta. Ocena stopnia spełnienia określonych kryteriów przez wybrane materiały geosyntetyczne pozwala na lepszą ocenę ich przydatności i dobór z zastosowaniem metod analizy wielokryterialnej. Tematem artykułu jest etap wstępny, czyli przygotowanie i uporządkowanie istotnych cech geosyntetyków i zdefiniowanie grup kryteriów głównych i podkryteriów.

Słowa kluczowe: geosyntetyki, klasyfikacja, zastosowanie geosyntetyków, kryteria oceny 